\title{
RETHINKING DESTINATION IMAGE FORMATION
}

\author{
Hidayet Kislali
}

PhD Candidate, School of Management, University of Leicester, UK

Mihalis Kavaratzis

PhD, Senior Lecturer in Marketing, School of Management, University of Leicester, UK

Michael Saren

Professor of Marketing, Head of Marketing Group, School of Management, University of Leicester, UK

\section{THIS IS A PRE-PUBLICATION VERSION OF:}

Kislali, H., Kavaratzis, M. and Saren, M. (2016) Rethinking destination

image formation, International Journal of Culture, Tourism and

Hospitality Research, 10(1), 70-80.

Please use this reference to cite this paper.

\section{INTRODUCTION}

As a consequence of increased competition for tourism investment and expenditure, differentiation of the destination's offering is considered a key part of a destination marketing strategy. It is argued that Destination Image (DI) has become a key element in marketing efforts aiming to differentiate a destination (e.g. Ekinci, 2003; Hosany et al, 2006). Therefore, understanding destination image formation is crucial for both tourism professionals and scholars.

Since the appearance of Hunt's (1975) seminal article 'Image as a Factor in Tourism Development', DI has become a concept on which dozens of articles have been published. Pike (2002) analyses 142 journal articles which were published between the years 1973-2000. The literature on destination image in general revolves around its conceptualisation (e.g. Gallarza et al, 2002; Tasci et al, 2007), its components (e.g. Garnter, 1994; Baloglou and McCleary, 1999), its measurement (e.g. Echtner and Ritchie, 1993; Govers et al, 2007) and its 
influence (e.g. Bigne et al, 2001; Prayag, 2009). Particularly, tourists' decision making process has been investigated extensively (e.g. Heitman, 2011) and it is acknowledged that Destination Image (DI) plays and essential role in this process ; Goodrich, 1978; Um \& Crompton, 1990). Despite this importance, as stated by Baloglu and McCleary(1999), "little empirical research has focused on how image is actually formed" (p.869) and there is a need for conceptual frameworks of the formation of DI (Gallarza et al., 2002; Lai \& Li, 2012). Notable influential suggestions include the works of Echtner \& Ritchie (1991), Gartner (1994) and Baloglu \& McCleary (1999). While these studies contribute significantly to our understanding of Destination Image formation, several socio-cultural factors and more recent technological changes, especially the influence of social media, have arguably not been considered. This paper attempts to contribute to a more nuanced understanding of destination image formation under the particular conditions created by the current economic, technological and social environment

\section{CONCEPTUALIZATION OF DESTINATION IMAGE}

In the early 1990s, Echtner and Ritchie $(1991 ; 1993)$ criticized the previous works as lacking theoretical conceptualizations. In order to address this gap in the literature, they tried to conceptualize DI through a three dimensional framework. According to this framework DI is formed along three continuums. The first continuum ranges from individual attributes to holistic impressions of a destination. While destination offerings and facilities, such as accommodation, transportation, and visitor attractions, can be considered as individual attributes of a destination, general feelings toward a destination are regarded as holistic impressions. The second continuum consists of functional characteristics, such as weather and landscapes at the one end, and psychological characteristics, for example atmosphere, safety and friendliness of locals, at the other end. The third continuum ranges from common image attributes to unique image attributes. Whereas common attributes can be found in all destinations, such as; whether, landscapes and public transport, and comparisons between different destinations are possible, unique attributes are exclusive to a specific destination (for instance the Eifel Tower in Paris, religious atmosphere in Vatican, and the Pyramids in Egypt). In their ground-breaking articles, Echtner and Ritchie (1991; 1993) emphasize that destinations do not only have individual attributes but also holistic imageries. Although there are significant number of studies dealing with individual attributes of destinations, holistic aspects of DI has been overlooked in tourism research (W. M. Choi, Chan, \& Wu, 1999; Ateljevic \& Doorne, 2002). Therefore, to better understand $\mathrm{DI}$, comprehensive studies which consider these overlooked aspects of DI seem to be essential. 
A few years later, Gartner (1994) tried to further investigate destination image formation. According to Gartner's (1994) conceptualisation, , DI consists of cognitive, affective and conative components. While cognitive component refer to knowledge and beliefs about a destination, affective image components refer to emotions, feelings, and attachment toward a destination. Based on the cognitive and affective evaluations, there is a conative image which refers to behavioural intentions of travellers. This conceptualization approaches DI as an attitudinal construct (Stern, Zinkhan, \& Jaju, 2001; Cian, 2011) and focuses on the image forming agents offering a useful framework to explain image formation. Gartner (1994) focuses particularly on the information sources used in image formation and their significant influence over the whole process. The claim is that if the importance of different information sources in image formation is known, a better image promotion mix can be developed to enhance destination images. An implication of this claim is the assumption that DMOs have control and power to manipulate destination images with a strategic promotion mix, which is seen as unlikely in tourism markets that are highly complex and competitive (Berne, Garcia-Gonzalez, \& Mugica, 2011; Buhalis, 1998).

Another highly influential model was developed by Baloglu and McCleary (1999). They define image as "an attitudinal construct consisting of an individual's mental representation of knowledge (beliefs), feelings, and global impression about an object or destination" (p.870). Their definition implies that DI consists of three interrelated constructs: cognitive, affective, and global. While both the Gartner (194) and the Baloglu and McClearly (1999) models are shaped around the causal relationships between cognitive and affective components (Lai \& Li, 2012), their main difference is that for Baloglu and McClearly (1999), the conative component suggested by Gartner (1994) is not considered as a part of DI. . Similar to Gartner, Baloglu and McClearly also mention that information sources play a very significant role in DI formation along with tourist motivations, and socio-demographic characteristics. However, their consideration of sociodemographic factors is based on a market segmentation understanding whereas more novel understandings of markets generally require a move beyond a segmented approach towards more fragmented views (e.g. Firat and Shultz II, This means that while studying image formation, consideration of subjective meanings may open new paths to explore the complex nature of DI. This requires embracing of wider socio-cultural understanding of the tourism phenomenon (Tribe, 2008; Tribe \& Xiao, 2011). Therefore, there is a need for comprehensive studies which consider socio-cultural, historical and economical situations of individuals.

Although valuable efforts have been devoted to conceptualize DI in 1990s, because of the complexity of DI, scholars keep trying to reconceptualise it in the new millennium. Based on a comprehensive literature review, Gallarza et al (2002) postulate that DI is a complex, multiple, relativistic, and dynamic concept. It is complex because it allows more than a single interpretation. Multiplicity of 
DI refers to its multiple components, from individual attributes to holistic impressions, and multi-disciplinary research on it. Since the tourism products are not generally available to pre-test before purchase, their evaluations are made with subjective judgements rather than objective realities. Therefore, each individual has a unique subjective image for a specific destination; therefore DI is a relativistic concept (Jenkins, 1999). Finally, DI is not a static concept; rather it is dynamic and it changes according to time and space. Tasci, Gartner and Cavusgil (2007) also try to reconceptualise DI, and define DI as "an interactive system of thoughts, opinions, feelings, visualizations, and intentions toward a destination" (p.200). One of the most recent conceptualizations has been offered by Lai and Li (2012). Unlike the earlier conceptualizations, DI is not considered as an attitudinal construct in this framework but rather as a collection of core- and periphery images. Although these recent conceptualizations (Lai \& Li, 2012; Tasci et al., 2007; Gallarza et al., 2002) try to consider complex and holistic aspects of $\mathrm{DI}$, these studies do not consider socio-cultural, historical, political and economic aspects in their definitions. They consider DI as a crucial tool for destination advertising (Ateljevic \& Doorne, 2002; Therkelsen, 2003), and pay insufficient attention to recent technological changes such as the rapid development of the internet and, particularly, social media. Therefore, there is still a need for comprehensive studies which consider the socio-cultural, historical, political, economic and technological factors.

\section{DESTINATION IMAGE FORMATION IN THE CONTEMPORARY ENVIRONMENT}

There have been spectacular changes in the ways the consumers receive and disseminate information about tourism products and services (Buhalis, 1998; Leung, Law, van Hoof, \& Buhalis, 2013). In the past, DMOs controlled the media messages, and tried to create desired destination images through their marketing campaigns, but today travellers do not need to rely on information coming from marketing channels. These changes in communication emancipate individuals from dominance of traditional information sources and open new research areas for scholars. Although there is an increased interest in social media among tourism researchers, the role of the social media and user generated content in DI formation is an area that needs to be further investigated.

Technological improvements are changing our lives, and bring new challenges and opportunities for organizations. As stated by Govers and Go (2009,p.1) "[i]n this present-day world of parallel virtual and 'real' experiences... [t]he common saying, 'It's a small world' is increasingly true". There have been spectacular changes in the ways the consumers receive, consume, and disseminate information about products and services (Hudson \& Thal, 2013). Tourism is one 
of the sectors which are mostly affected from these changes (Buhalis, 1998; Leung et al., 2013). Recently, tourism has become the number one industry for the online transactions volume (Mack, Blose, \& Bing Pan, 2008). The rapid increase in internet and social media usage brings new challenges and opportunities both for tourism destinations and travellers (Schmallegger \& Carson, 2008) because it changes the information search and purchase behaviours of travellers (Lo, McKercher, Lo, Cheung, \& Law, 2011), ultimately impacting on the way in which destination images are formed. The internet offers extensive opportunities for immediate and direct relationships between market constituents and this has severe consequences for the processes that form images. Online communication technologies and, particularly, social media facilitate and encourage rapid interactions not only between companies (such as DMOs) and consumers but, more importantly, between consumers themselves. The ease of information access and the readily available multitude of communication channels clearly impact on the way in which destinations are represented.

In the past, DMOs controlled the media messages, and they tried to create desired destination images through their marketing campaigns, but traditional destination marketing has been challenged by appearance of social media applications and user generated contents (Frías et al 2012; Gretzel, 2006; Munar, 2012) because travellers do not need to rely on information received from controlled sources. They can communicate time efficiently and cost effectively not only with previous visitors to a destination but also with accommodation suppliers, travel companies, DMOs, and local residents of a destination through social media platforms, (Hvass \& Munar, 2012; Lin \& Huang, 2006; Pan \& Fesenmaier, 2006; Xiang \& Gretzel, 2010). Since the contents of social media platforms are not directly controlled by DMOs, they include both positive and negative comments about destinations. These comments affect and change the perceptions of potential travellers (Carson, 2008; Lo et al., 2011; Miguéns, Baggio, \& Costa, 2008). However, there is scepticism about the credibility and trustworthiness of these comments. When people receive information through Word-of-Mouth (WOM), they usually find it credible since it comes from a known source, but in terms of e-WOM the situation is not the same since the source is unknown. Therefore, it is stated that consumers perceive e-WOM as less credible than traditional WOM (Ayeh, Au, \& Law, 2013; Bronner \& de Hoog, 2011; Prebensen, Skallerud, \& Chen, 2010). This indicates the rather urgent need to further investigate the formation of DI considering the technological changes and the perceived credibility of the information received through social media platforms. 


\section{RE-CONCEPTUALIZATION OF DESTINATION IMAGE}

Similar to the general marketing discipline, research in tourism has been mainly directed by firm-based understanding of marketing and the marketing environment. Because the wider socio-cultural and historical context of tourism markets is assumed to be too complex (Fesenmaier \& Mackay, 1996; Pike, 2005) to attempt to influence it, the attention of tourism researchers have been mainly focused on the firm- based (DMOs) promotional activities. This narrow understanding of tourism and destination has resulted in a lack of research for the socio-cultural and historical aspects in tourism (Venkatesh \& Peñaloza, 2006). While there are some attempts to explore holistic nature of DI through qualitative investigations (Cave, Ryan, \& Panakera, 2007; Reilly, 1990; Ryan \& Cave, 2005), their attempts were overlooked by traditional tourism studies. Holistic approaches to what destinations are (e.g. Saraniemi and Kylanen, 2011) and how their images are formed (Gallarza et al, 2002) help go beyond monolithic views of destinations and thie images. For instance, as briefly mentioned above, the insightful analysis of Gallarza et al (2002) concludes that destination images are complex in that they are not unequivocal, they are multiple in the elements and processes that construct them, they are relativistic in that they are subjective and they are dynamic in that they vary with the dimensions of time and space. Snepenger et al (2007) describe places as 'storehouses of meanings', capturing the ways in which place meaning is defined by visitors and locals through being there, through their consumption practices and through their interactions. Cultural and sociological approaches suggest that places are best thought of as "results of social practice and, thus, processual structures of meanings and values" (Saraniemi and Kylanen, 2011: 138) replacing the traditional, "clumsy and technical supply-demand divisions" (p. 140). For Creswell (2004), places are constructed by people doing things and in this sense are never 'finished' but are constantly being performed.

One of the implications of such novel and nuanced understandings of destinations and their images is that traditional structured methods may not capture holistic aspects of DI (Echtner \& Ritchie, 1991) although the vast majority of researchers rely on structured methodologies of post/positivist paradigms. Since the positivist research in tourism offers a better operationalization of tourism management (Tribe, 2008), research developed in this paradigm favours the managerial understanding of tourism. This can be seen as leading to research that silences the voice of individuals. Therefore, studies which do not only consider managerial aspects of tourism need to be conducted to understand formation of DI (Canally, 2010).

As stated above, only a handful of scholars try to conceptualize DI. The concept of DI is understood vaguely and mainly considered as the sum of the individual attributes by significant amount of scholars (Therkelsen, 2003). We see this as a potentially significant problem in tourism research. Since researchers try to understand and measure each attribute of a destination individually, it becomes 
too difficult to capture holistic meanings, atmospheres and auras in a destination (Jenkins, 1999). Furthermore, there is ambiguity on a commonly accepted definition of $\mathrm{DI}$ among tourism scholars. While many studies do not include a specific definition, others cite many definitions without an evaluation of the one they are based on. When the literature is reviewed it can be seen that scholars do not use $\mathrm{DI}$ as a single term but to cover several aspects and types of destination images, arguably reflecting the complexity of the concept. There is projected image, which is the image promoted by DMOs, and this is not the one which is constructed in the minds of individuals (Jenkins, 1999; Kim \& Lehto, 2013).This image which is constructed in the minds of individuals is called perceived image (Baloglu \& Mangaloglu, 2001; Beerli \& Martín, 2004; Chen \& $\mathrm{Hsu}, 2000)$. The perceived image is also divided into primary and secondary images. While primary image refers to more complex image constructed after the personal experience of a destination, secondary image is the one based on the induced and organic information sources (Gartner, 1994; Jenkins, 1999; Tasci et al., 2007). These categories may signal that DI is a construct that can be easily divided into individual parts; however, our understanding of DI is as holistic as in the Crompton's (1979) definition. He defines DI as "sum of beliefs, ideas, [feelings] and impressions that a person has of a destination" (p.18).

Our review of the literature leads to see DI as a holistic construct rather than a total of individual attributes (Echtner \& Ritchie, 1991; Reilly, 1990). Therefore, the framework presented in Figure 1 will guide our (re)conceptualization DI and to understand its formation. Although it may not be possible to present a complex and multi-dimensional construct (Gallarza et al., 2002; Pike, 2005) in a simplistic figure, this model may help to better conceptualization by stressing roles of diverse influencing factors in destination image formation.

Figure1 shows that a DMO starts to project an image through different media channels. This is the desired image that the DMO wants to create in the minds of potential travellers (Mak, 2011). However, since individuals may have some information about the specific destinations through organic sources, such as TV, internet, books, magazines, relatives and friends; they almost inevitably have an organic image in their minds (Gartner, 1994; Jenkins, 1999). Therefore, when they perceive promotional messages from different media channels, the organic images in their minds may or may not change (Ekinci, 2003; Tasci \& Kozak, 2006). Although this might be explained as a sequence, these organic and induced images may not be easily distinguished from each other, and either induced or organic images may be constructed earlier than the other. Because these organic and induced images are constructed prior to actual visitation of a destination they are called secondary images (Gartner, 1994). As suggested in Figure 1, the image projected by the destination has an impact on these secondary images, but there are other factors such as culture, history, politics, economics, technology and motivations which may influence the formation of images (Canally, 2010; Fesenmaier \& MacKay, 1996) Therefore, in order to explore pre- 
visit perceptions of individuals, or the secondary images in their minds, these factors needs to be taken into account. When someone visits a destination, destination image in his/her mind becomes richer and more complex. This is called primary image since it is based on the first-hand experiences (Gartner, 1994; Jenkins, 1999). To distinguish the role of experiences in DI formation, both the primary and secondary images in the minds of individuals needs to be further investigated. The conceptual framework depicted in Figure 1 will guide an elaborate empirical study that will investigate destination image formation incorporating the factors identified here.

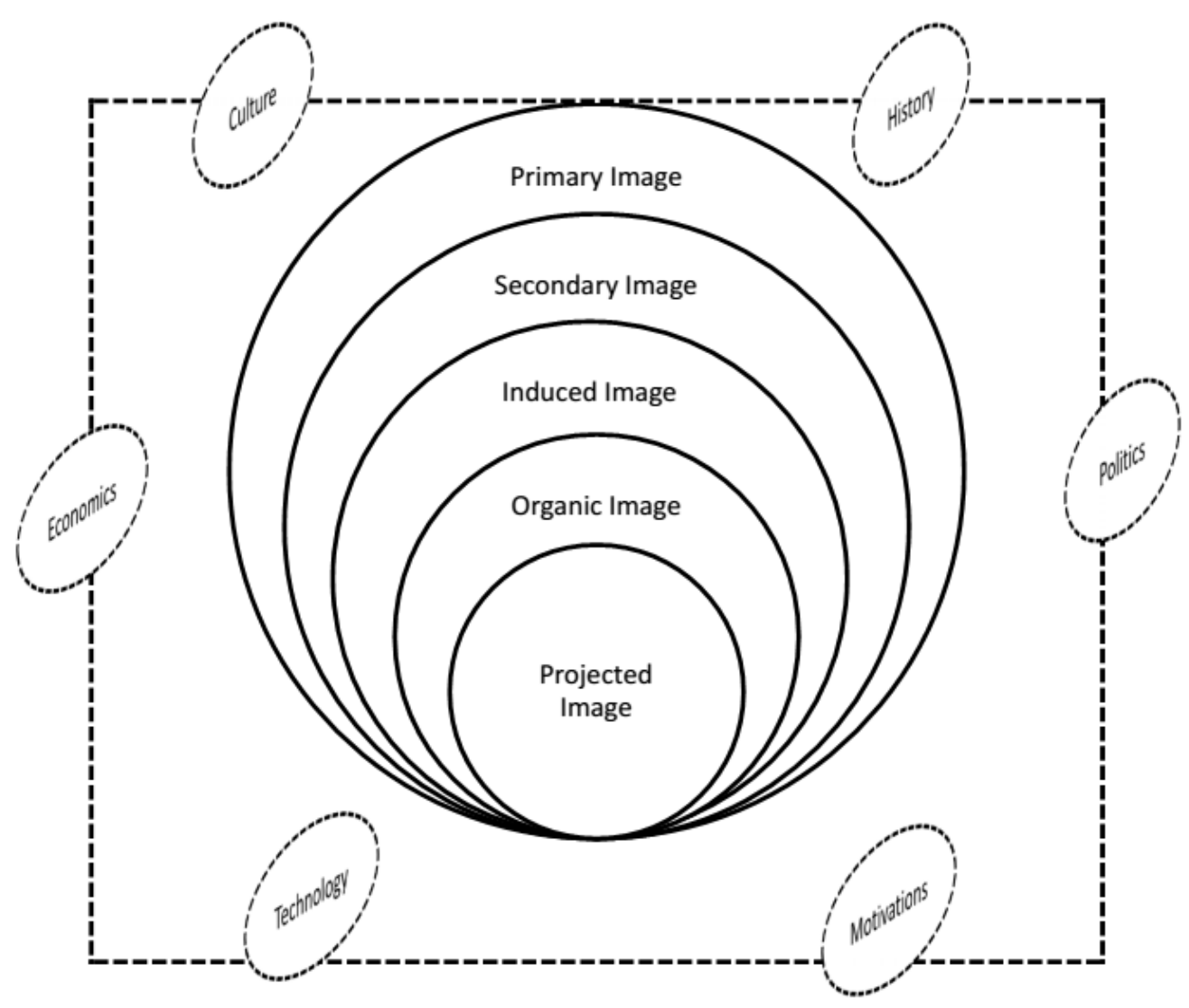

Figure 1: Proposed Framework to Conceptualize Destination Image Formation

\section{CONCLUSION}

Although tourism scholars have been studying destination image for more than three decades, there are only few studies that contribute significantly to our understanding of DI formation (Baloglu \& McCleary, 1999; Echtner \& Ritchie, 
1991; Gallarza et al., 2002; Lai \& Li, 2012; Tasci et al., 2007). We have identified above the need to consider socio-cultural factors and recent technological changes in such conceptualizations (Canally, 2010). Perhaps as a consequence of post/positivist understanding of tourism phenomenon, DI research seems to be dominated by quantitative structured research methods (Ateljevic et al., 2007; Tribe, 2008; Goodson \& Phillimore, 2004) whereas qualitative studies might be more appropriate to capture the processes that allow individuals to construct destination images in their minds. Although there are recent attempts to bring wider social science perspectives to tourism studies, further research is necessary in order to contribute to a better conceptualization of destination image and shed a light to overlooked socio-cultural aspects of tourism along with recent technological changes. The study that will follow this conceptual paper will attempt to provide novel explanations of destination image formation in the contemporary environment and help both scholars and destination managers deal with these complex processes.

\section{REFERENCES}

Ateljevic, I., \& Doorne, S. (2002). Representing new zealand: Tourism imagery and ideology. Annals of Tourism Research, 29(3), 648-667. doi:http://dx.doi.org/10.1016/S0160-7383(01)00077-9

Ateljevic, I., Morgan, N., \& Pritchard, A. (2007). Editors' introduction: Promoting an academy of hope in tourism enquiry. In I. Ateljevic, A. Pritchard \& N. Morgan (Eds.), The critical turn in tourism studies (pp. 1-8). Oxford: Elsevier. doi:http://dx.doi.org/10.1016/B978-0-08-045098-8.50005-2

Ayeh, J. K., Au, N., \& Law, R. (2013). "Do we believe in TripAdvisor?" examining credibility perceptions and online travelers' attitude toward using usergenerated content. Journal of Travel Research, 52(4), 437-452. doi:10.1177/0047287512475217

Baloglu, S., \& Mangaloglu, M. (2001). Tourism destination images of turkey, egypt, greece, and italy as perceived by US-based tour operators and travel agents. Tourism Management, 22(1), 1-9. doi:10.1016/S02615177(00)00030-3

Baloglu, S., \& McCleary, K. W. (1999). A model of destination image formation. Annals of Tourism Research, 26(4), 868-897. doi:10.1016/S01607383(99)00030-4 
Beerli, A., \& Martín, J. D. (2004). Factors influencing destination image. Annals of Tourism Research, 31(3), 657-681. doi:10.1016/j.annals.2004.01.010

Beerli, A., \& Martín, J. D. (2004). Tourists' characteristics and the perceived image of tourist destinations: A quantitative analysis - a case study of lanzarote, spain. Tourism Management, 25(5), 623-636. doi:10.1016/j.tourman.2003.06.004

Berne, C., Garcia-Gonzalez, M., \& Mugica, J. (2011). How ICT shifts the power balance of tourism distribution channels. Tourism Management, 33(1), 205.

Blain, C., Levy, S. E., \& Ritchie, J. R. B. (2005). Destination branding: Insights and practices from destination management organizations. Journal of Travel Research, 43(4), 328-338. doi:10.1177/0047287505274646

Bronner, F., \& de Hoog, R. (2011). Vacationers and eWOM: Who posts, and why, where, and what? Journal of Travel Research, 50(1), 15-26. doi:10.1177/0047287509355324

Buhalis, D. (1998). Strategic use of information technologies in the tourism industry. Tourism Management, 19(5), 409-421. doi:http://dx.doi.org/10.1016/S0261-5177(98)00038-7

Canally, C., Richard. (2010). An exploration of american and canadian tourist destination images of cuba. (Unpublished Wilfrid Laurier University,

Carson, D. (2008). The 'blogosphere' as a market research tool for tourism destinations: A case study of australia's northern territory. Journal of Vacation Marketing, 14(2), 111-119. doi:10.1177/1356766707087518

Cave, J., Ryan, C., \& Panakera, C. (2007). Cultural tourism product: Pacific island migrant perspectives in new zealand. Journal of Travel Research, 45(4), 435443. doi:10.1177/0047287506295908

Chen, J. S., \& Hsu, C. H. C. (2000). Measurement of korean tourists' perceived images of overseas destinations. Journal of Travel Research, 38(4), 411-416. doi:10.1177/004728750003800410

Choi, S., Lehto, X. Y., \& Morrison, A. M. (2007). Destination image representation on the web: Content analysis of macau travel related websites. Tourism Management, 28(1), 118-129. doi:http://dx.doi.org/10.1016/j.tourman.2006.03.002 
Choi, W. M., Chan, A., \& Wu, J. (1999). A qualitative and quantitative assessment of hong kong's image as a tourist destination. Tourism Management, 20(3), 361-365. doi:10.1016/S0261-5177(98)00116-2

Chon, K. (1993). The role of destination image in tourism: A review and discussion. Tourism Review, 45(2), 2-9. doi:10.1108/eb058040

Cian, L. (2011). How to measure brand image: A reasoned review. Marketing Review, 11(2), 165-187. doi:10.1362/146934711X589390

Crompton, J. L. (1979). An assessment of the image of mexico as a vacation destination and the influence of geographical location upon that image. Journal of Travel Research, 17(4), 18-23. doi:10.1177/004728757901700404

Echtner, C. M., \& Ritchie, J. R. B. (1993). The measurement of destination image: An empirical assessment. Journal of Travel Research, 31(4), 3-13. doi:10.1177/004728759303100402

Echtner, C. M., \& Ritchie, J. R. B. (1991). The meaning and Measurement of Destination Image. The Journal of Tourism Studies, 2(2), 2-12.

Ekinci, Y. (2003). From destination image to destination branding: An emerging area of research. E-Review of Tourism Research (eRTR), 1(2), 21-24.

Fesenmaier, D., \& MacKay, K. (1996). Deconstructing destination image construction. Tourism Review, 51(2), 37-43. doi:10.1108/eb058222

Firat, A. F., \& Shultz II, C. J. (1997). From segmentation to fragmentation: Markets and marketing strategy in the postmodern era. European Journal of Marketing, 31(3), 183-207. doi:10.1108/EUM0000000004321

Frías, D. M., Rodríguez, M. A., Alberto Castañeda, J., Sabiote, C. M., \& Buhalis, D. (2012). The formation of a tourist destination's image via information sources: The moderating effect of culture. International Journal of Tourism Research, 14(5), 437-450. doi:10.1002/jtr.870

Gallarza, M. G., Saura, I. G., \& García, H. C. (2002). Destination image: Towards a conceptual framework. Annals of Tourism Research, 29(1), 56-78. doi:10.1016/S0160-7383(01)00031-7

Gartner, W. C. (1994). Image formation process. Journal of Travel \& Tourism Marketing, 2(2-3), 191-216. doi:10.1300/J073v02n02_12 
Goodrich, J. N. (1978). The relationship between preferences for and perceptions of vacation destinations: Application of a choice model. Journal of Travel Research, 17(2), 8-13. doi:10.1177/004728757801700202

Goodson, L., \& Phillimore, J. (2004). The inquiry paradigm in qualitative tourism research. In J. Phillimore, \& L. Goodson (Eds.), Qualitative research in tourism: Ontologies, epistemologies and methodologies (pp. 30-45). London: Routledge.

Govers, R., \& Go, F. (2009). Place branding-glocal,virtual, and physical identities, constructed,imagined and experienced. Chippenham and Eastbourne: Palgrave Macmillan.

Gretzel, U. (2006). Consumer generated content - trends and implications for branding. E-Review of Tourism Research (eRTR), 4(3), 9-11.

Heitmann, S. (2011). Tourist behaviour and tourism motivation $<b r />$. In P. Robinson, S. Heitmann \& P. U. C. Dieke (Eds.), Research themes for tourism (pp. 31-44). Wallingford, Oxon, GBR: CABI Publishing.

Hong, S., Kim, J., Jang, H., \& Lee, S. (2006). The roles of categorization, affective image and constraints on destination choice: An application of the NMNL model. Tourism Management, 27(5), 750-761.

doi:10.1016/j.tourman.2005.11.001

Hosany, S., Ekinci, Y., \& Uysal, M. (2006). Destination image and destination personality: An application of branding theories to tourism places. Journal of Business Research, 59(5), 638-642. doi:http://dx.doi.org/10.1016/j.jbusres.2006.01.001

Hudson, S., \& Thal, K. (2013). The impact of social media on the consumer decision process: Implications for tourism marketing. Journal of Travel \& Tourism Marketing, 30(1-2), 156-160. doi:10.1080/10548408.2013.751276

Humberstone, B. (2004). Standpoint reseach: Multiple versions of reality in tourism theorising and research. In J. Phillimore, \& L. Goodson (Eds.), Qualitative research in tourism: Ontologies, epistemologies and methodologies (pp. 119-136). London: Routledge.

Hunt, J. D. (1975). Image as a factor in tourism development. Journal of Travel Research, 13(3), 1-7. doi:10.1177/004728757501300301

Hvass, K. A., \& Munar, A. M. (2012). The takeoff of social media in tourism. Journal of Vacation Marketing, 18(2), 93-103. doi:10.1177/1356766711435978 
Jenkins, O. H. (1999). Understanding and measuring tourist destination images. International Journal of Tourism Research, 1(1), 1-15. doi:10.1002/(SICI)1522-1970(199901/02)1:1<1::AID-JTR143>3.0.CO;2-L

Jennings, G., R. (2012). Qualitative research: Its nature and evaluation. In L. Dwyer, A. Gill \& N. Seetaram (Eds.), Handbook of research methods in tourism (pp. 309-323). Cheltenham: Edward Elgar.

Kim, S., \& Lehto, X. Y. (2013). Projected and perceived destination brand personalities: The case of south korea. Journal of Travel Research, 52(1), 117-130. doi:10.1177/0047287512457259

Lai, K., \& Li, Y. (2012). Core-periphery structure of destination image: Concept, evidence and implication. Annals of Tourism Research, 39(3), 1359-1379. doi:10.1016/j.annals.2012.02.008

Leung, D., Law, R., van Hoof, H., \& Buhalis, D. (2013). Social media in tourism and hospitality: A literature review. Journal of Travel \& Tourism Marketing, 30(12), 3-22. doi:10.1080/10548408.2013.750919

Lin, Y., \& Huang, J. (2006). Internet blogs as a tourism marketing medium: A case study. Journal of Business Research, 59(10-11), 1201-1205. doi:http://dx.doi.org/10.1016/j.jbusres.2005.11.005

Lo, I. S., McKercher, B., Lo, A., Cheung, C., \& Law, R. (2011). Tourism and online photography. Tourism Management, 32(4), 725-731. doi:http://dx.doi.org/10.1016/i.tourman.2010.06.001

Mack, R. W., Blose, J. E., \& Bing Pan,. (2008). Believe it or not: Credibility of blogs in tourism. Journal of Vacation Marketing, 14(2), 133-144. doi:10.1177/1356766707087521

Mak, A. K. Y. (2011). An identity-centered approach to place branding: Case of industry partners' evaluation of iowa's destination image. Journal of Brand Management, 18(6), 438-450. doi:10.1057/bm.2010.56

Miguéns, J., Baggio, R., \& Costa, C. (2008). Soacial media and tourism destinations:TripAdvisor case study. Advances in Tourism Reseach 2008, Aveiro, Portugal.

Munar, A. M. (2012). Social media strategies and destination management. Scandinavian Journal of Hospitality and Tourism, 12(2), 101-120. doi:10.1080/15022250.2012.679047 
Murphy, L., Moscardo, G., \& Benckendorff, P. (2007). Using brand personality to differentiate regional tourism destinations. Journal of Travel Research, 46(1), 5-14. doi:10.1177/0047287507302371

Pan, B., \& Fesenmaier, D. R. (2006). Online information search: Vacation planning process. Annals of Tourism Research, 33(3), 809-832. doi:http://dx.doi.org/10.1016/i.annals.2006.03.006

Pike, S. (2002). Destination image analysis-a review of 142 papers from 1973 to 2000. Tourism Management, 23(5), 541-549. doi:10.1016/S02615177(02)00005-5

Pike, S. (2005). Tourism destination branding complexity. Journal of Product \& Brand Management, 14(4), 258-259. doi:10.1108/10610420510609267

Prebensen, N., Skallerud, K., \& Chen, J. S. (2010). Tourist motivation with sun and sand destinations: Satisfaction and the wom-effect. Journal of Travel \& Tourism Marketing, 27(8), 858-873. doi:10.1080/10548408.2010.527253

Reilly, M. D. (1990). Free elicitation of descriptive adjectives for tourism image assessment. Journal of Travel Research, 28(4), 21-26.

doi:10.1177/004728759002800405

Ryan, C., \& Cave, J. (2005). Structuring destination image: A qualitative approach. Journal of Travel Research, 44(2), 143-150. doi:10.1177/0047287505278991

Schmallegger, D., \& Carson, D. (2008). Blogs in tourism: Changing approaches to information exchange. Journal of Vacation Marketing, 14(2), 99-110. doi:10.1177/1356766707087519

Stern, B., Zinkhan, G. M., \& Jaju, A. (2001). Marketing images: Construct definition, measurement issues, and theory development. Marketing Theory, 1(2), 201-224. doi:10.1177/147059310100100203

Tasci, A. D. A. (2011). Destination branding and positioning. In Y. Wang, \& A. Pizam (Eds.), Destination marketing and management-theories and applications (pp. 113-129). Wallingford,UK: CABI.

Tasci, A. D. A., Gartner, W. C., \& Cavusgil, S. T. (2007). Conceptualization and operationalization of destination image. Journal of Hospitality \& Tourism Research, 31(2), 194-223. doi:10.1177/1096348006297290

Tasci, A. D. A., \& Kozak, M. (2006). Destination brands vs destination images: Do we know what we mean? Journal of Vacation Marketing, 12(4), 299-317. doi:10.1177/1356766706067603 
Therkelsen, A. (2003). Imagining places: Image formation of tourists and its consequences for destination promotion. Scandinavian Journal of Hospitality and Tourism, 3(2), 134-150. doi:10.1080/15022250310003105

Tribe, J. (1997). The indiscipline of tourism. Annals of Tourism Research, 24(3), 638-657. doi:http://dx.doi.org/10.1016/S0160-7383(97)00020-0

Tribe, J. (2008). Tourism: A critical business. Journal of Travel Research, 46(3), 245-255. doi:10.1177/0047287507304051

Tribe, J., \& Airey, D. (2007). A review of tourism research. In J. Tribe, \& D. Airey (Eds.), Developments in tourism research (pp. 3-14). Oxford: Elsevier. doi:http://dx.doi.org/10.1016/B978-0-08-045328-6.50005-4

Tribe, J., \& Xiao, H. (2011). Developments in tourism social science. Annals of Tourism Research, 38(1), 7-26.

doi:http://dx.doi.org/10.1016/j.annals.2010.11.012

Um, S., \& Crompton, J. L. (1990). Attitude determinants in tourism destination choice. Annals of Tourism Research, 17(3), 432-448. doi:10.1016/01607383(90)90008-F

Venkatesh, A., \& Peñaloza, L. (2006). From marketing to market: A call for paradigm shift. In J. N. Sheth, \& R. S. Sisodia (Eds.), Does marketing need reform? : Fresh perspectives on the future (pp. 134-150). Armonk, NY, USA: M.E. Sharpe, Inc.

World Tourism Organization. (2013). UNWTO tourism highlights. (). Madrid: World Tourism Organization.

Xiang, Z., \& Gretzel, U. (2010). Role of social media in online travel information search. Tourism Management, 31, 179-188. 
